\title{
Overexpression of the pineapple fruit bromelain gene (BAA) in transgenic Chinese cabbage (Brassica rapa) results in enhanced resistance to bacterial soft rot
}

\author{
Yu-Jin Jung \\ Department of Horticulture \\ Hankyong National University \\ 67 Sukjong-dong, Ansung city \\ Kyonggi-do 456-749, South Korea \\ Tel: 82316705107 \\ Fax: 82316705333 \\ E-mail: yuyu1216@naver.com \\ Chang-Sun Choi \\ Department of Horticulture \\ Hankyong National University \\ 67 Sukjong-dong, Ansung city \\ Kyonggi-do 456-749, South Korea \\ Tel: 82316705107 \\ Fax: 82316705333 \\ E-mail: sunlog@naver.com \\ Jin-Heui Park \\ Department of Horticulture \\ Hankyong National University \\ 67 Sukjong-dong, Ansung city \\ Kyonggi-do 456-749, South Korea \\ Tel: 82316705107 \\ Fax: 82316705333 \\ E-mail: jinnysendai@hanmail.net

\section{Hee-Wan Kang} \\ Graduate School of Bio-Information Technology \\ Hankyong National University \\ 67 Sukjong-dong, Ansung city \\ Kyonggi-do 456-749, South Korea \\ Tel: 82316705420 \\ Fax: 82316705420 \\ E-mail: kanghw2@hknu.ac.kr

\section{Je-Eul Choi} \\ Department of Agronomy \\ College of Agriculture \\ Chungnam National University \\ Daejeon 305-764, South Korea \\ Tel: 0428215729 \\ Fax: 0428215729 \\ E-mail: choije@cnu.ac.kr

\section{Ill-Sup Nou} \\ Faculty of Plant Science and Production \\ Sunchon National University \\ Sunchon 540-742, South Korea \\ Tel: 0617503249 \\ Fax: 0617503249 \\ E-mail: nis@sunchon.ac.kr

\section{Soon Youl Lee*} \\ School of Applied Life Sciences \\ Genetic Informatics Center, GRRC \\ Hankyong National University \\ 67 Sukjong-dong, Ansung city \\ Kyonggi-do 456-749, South Korea \\ Tel: 82316705333
}




\author{
Fax: 82316705333 \\ E-mail: sylee@hknu.ac.kr

\section{Kwon-Kyoo Kang*} \\ Department of Horticulture \\ Hankyong National University \\ 67 Sukjong-dong, Ansung city \\ Kyonggi-do 456-749, South Korea \\ Tel: 82316705104 \\ Fax: 82316705333 \\ E-mail: kykang@hknu.ac.kr
}

Financial support: This work was supported by a grant from the Agricultural R\&D Promotion Center (Project No. 204068-3).

Keywords: Brassica rapa, fruit bromelain, soft rot resistance, transgenic plant.

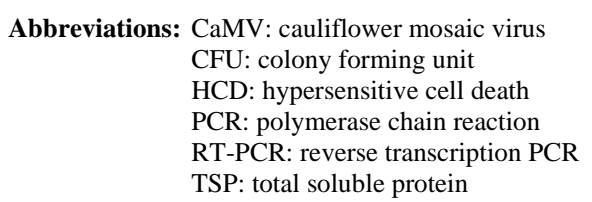

Abbreviations: CaMV: cauliflower mosaic virus

CFU: colony forming unit

HCD: hypersensitive cell death

PCR: polymerase chain reaction

RT-PCR: reverse transcription PCR

TSP: total soluble protein

\begin{abstract}
Bromelain is a crude protein extract obtained from pineapple stems, which comprises a variety of proteolytic enzymes. It exhibits potential therapeutic activities against trauma, inflammation, autoimmune diseases and malignant disorders. In this study, we cloned BAA1 (the gene encoding fruit bromelain) into a plant expression vector that was then used to transform Brassica rapa and overexpress BAA1 under the control of the cauliflower mosaic virus (CaMV) 35S promoter. We demonstrate that constitutive overexpression of $B A A 1$ in $B$. rapa confers enhanced resistance to the soft rot pathogen Pectobacterium carotovorum ssp. carotovorum. These results suggest that it could be utilized for protecting plants from attack by bacterial pathogens.
\end{abstract}

Bacterial soft rot is a common disease caused by Pectobacterium carotovorum ssp. carotovorum, which causes serious damage and economic losses in many vegetable crops including carrot, radish, potato and all types of Brassica. It is considered one of the most destructive diseases of Chinese cabbage (Brassica rapa), which is cultivated throughout China, Japan, and Korea (Kikumoto, 1981; Li, 1981). Plants employ a complex array of defense mechanisms to protect against invading phytopathogenic microorganisms. For example, plants will fortify their cell walls as a physical barrier and synthesize antimicrobial compounds such as phytoalexins (Dixon, 1986), pathogenesis related (PR) proteins (van Loon and van Kammen, 1970; Linthorst, 1991; Yun et al. 1997), thionins, ribosome-inactivating proteins, defensins and nonspecific-lipid transfer proteins (Broekaert et al. 1997).

Bacterial soft rot disease is hard to prevent due to the broad host range and latency in crop waste. Since chemical control is not developed yet, traditional cultural practice is still applied to prevent soft rot disease in Chinese cabbage. However, there are some reports showing increased resistance to soft rot by conventional breeding methods. When interspecific hybridization was performed either by sexual cross or somatic cell fusion of Chinese cabbage plus Kale, the progeny showed increased resistance to soft rot (Yoshikawa et al. 1989; Yamagishi et al. 1990).

Recently, transgenic plants expressing several genes were reported to show resistance to the soft rot-causing bacterial pathogen. The presence of pflp (ferredoxin-like protein) gene in the transgenic plant showed the increased resistance to bacterial pathogen (Yip et al. 2007). In addition, transgenic potatoes expressing heterogeneously ATP/ADP transporter gene (Linke et al. 2002) and bacterial pheromone $\mathrm{N}$-acyl-homoserine lactone synthesis gene (Toth et al. 2004) showed much improved resistance to soft rot.

Bromelain (EC 3.4.22.4) was isolated from the stem of pineapples and was characterized as a complex of cysteine proteases (Taussig and Batkin, 1988; Maurer, 2001). Cysteine proteases are involved in various physiological and developmental processes in plants including programmed cell death during organ senescence and

*Corresponding authors 
tracheary element differentiation (Beers et al. 2000; Subbaiah et al. 2000; Lam, 2005; Beyene et al. 2006). The precise roles of proteinases in these and other plant programmed cell death processes are under investigation (Beers et al. 2000).

Bromelain is reported to have a number of potential therapeutic applications, including treatment of trauma, inflammation, autoimmune diseases, enhancement of immune response, and malignant disorders (Maurer, 2001; Orsini, 2006). When used in conjunction with antibiotic therapy, bromelain has been shown to increase antibiotic effectiveness and absorption (Luerti and Vignali, 1978;

Tinozzi and Venegoni, 1978). In addition, bromelain is known to be relatively safe and not to show side effects, toxicity and resistance (Mynott et al. 2002). However, the mechanisms underlying these pharmacological effects remain not understood.

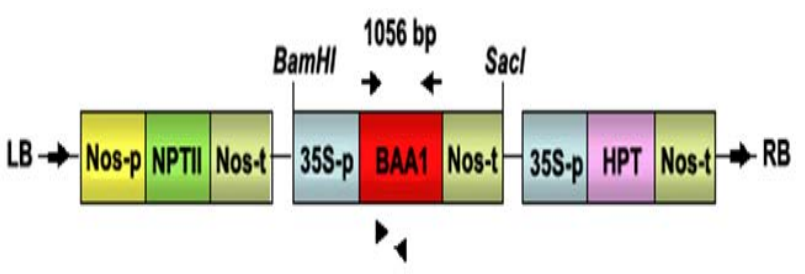

Figure 1. BAA1 was expressed in the binary plant expression vector pIG $121 \mathrm{Hm}$. Nos-p: nos promoter; HPT: gene encoding hygromycin phosphotransferase; Nos-t: nos terminator; 35S-p: CMV 35S promoter; BAA1: gene encoding fruit bromelain; LB: left border; and RB: right border. Primers for RT-PCR for cloning of $B A A 1$ gene (arrows) and primers for real-time PCR of BAA1 gene (arrowhead) are indicated.

The 1056 bp BAA1 gene encoding pineapple bromelain was cloned and the gene product was grouped to be a peptidase C1A subfamily, composed of cysteine peptidases (CPs) similar to papain, including the mammalian CPs (cathepsins) (Muta et al. 1993). Even though several protease and cathepsins were reported to be involved in the host-defense mechanism (Tani et al. 2001; Shafer et al. 2002) and to show antimicrobial activity, the exact physiological role of the $B A A 1$ in the plant defense system is not well characterized yet.

In this study, we wanted to know whether bromelain protease has an antimicrobial activity when expressed in plants since the role of bromelain has been reported in a number of potential therapeutic applications and to increase antibiotic effectiveness as described above. We isolated $B A A 1$, which encodes bromelain cysteine protease from pineapple (Ananas comosus L. Merrill) and over-expressed this gene in $B$. rapa. We then investigated the resistance of the resulting transgenic plants to bacteria using a Pectobacterium carotovorum ssp. carotovorum bioassay.

\section{MATERIALS AND METHODS}

\section{Transgene construction, preparation of explants, bacterial strain and transformation}

We isolated BAA1 cDNA from total RNA extracted from pineapple fruit using the primers BAA-F (5'-ATG GCT TCC AAA GTT CAA CTC GTG-3') and BAA-R (5'-TCA AGT TTC AGA AAC CAT CTT-3'), which were based on the published sequence (GenBank: GI2342495). The BAA1 cDNA was cloned into a transgene cassette under the control of the cauliflower mosaic virus 35S promoter (CaMV 35S promoter), then subcloned into the binary Tiplasmid vector pIG $121 \mathrm{Hm}$ (Clontech, Palo Alto, CA, U.S.A), which contains both kanamycin and hygromycin resistance genes for bacterial and plant transformation selection, respectively (Figure 1).

For sterilization, seeds were submerged in $70 \%$ ethanol for $2 \mathrm{~min}$, then in 1.5\% NaOCL for $10 \mathrm{~min}$. They were then rinsed eight times with sterilized water and plated onto MS medium (Murashige and Skoog, 1962) and incubated under light conditions for 6 days. Following germination, the hypocotyls were cut into $c a$. 5-7 mm segments and pre-cultured for 2 days on MS solid medium containing $1 \mathrm{mg} / \mathrm{L}$ 6-Benzyladenine (6-BA) and $1 \mathrm{mg} / \mathrm{L} \alpha$ naphthaleneacetic acid (NAA). Explants were then used for transformation. Glycerol stocks of Agrobacterium tumefaciens LBA4404 were used to inoculate liquid YEB medium ( $\mathrm{pH} 7.2)$ containing $5 \mathrm{~g} / \mathrm{L}$ tryptone, $5 \mathrm{~g} / \mathrm{L}$ yeast extract, $5 \mathrm{~g} / \mathrm{L}$ sucrose, $2 \mathrm{mM} \mathrm{MgSO}_{4}$ and $50 \mathrm{mg} / \mathrm{L}$ kanamycin, then incubated overnight at $27-28^{\circ} \mathrm{C}$ with constant shaking $(200 \mathrm{rpm})$. At mid-log phase of $\mathrm{OD}_{600}$ value of $0.9,0.1 \%$ of the culture was transferred to fresh medium and cultivated to $\mathrm{OD}_{600}=0.4$. Cells were collected by centrifugation and re-suspended in sterilized water.

Explants were immersed in the bacterial suspension for 2-3 min with constant shaking. The infected hypocotyls were then blotted onto filter paper and then transferred on the MS plate without any antibiotics and was incubated for 2 days at $25^{\circ} \mathrm{C}$ under dark. It was then transferred on callus induction medium (CIM; B5 salts, 1 $\mathrm{mg} / \mathrm{L}$ 2,4-D, 3\% (w/v) sucrose, 0.8\% (w/v) agar, $500 \mathrm{mg} / \mathrm{L}$ carbenicillin) and incubated for 14 days at $25^{\circ} \mathrm{C}$ under 16 hrs light / 8 hrs dark photoperiod. Finally, it was moved onto differentiation medium (DM; B5 salts, $3 \mathrm{mg} / \mathrm{L}$ BAP, $1 \mathrm{mg} / \mathrm{L}$ zeatin, 3\% (w/v) sucrose, 0.8\% (w/v) agar, $50 \mathrm{mg} / \mathrm{L}$ hygromycin, $500 \mathrm{mg} / \mathrm{L}$ carbenicillin) and grown for 14 days. It was subcultured 3 more times every 14 days. Differentiated shoots were moved to maturing medium (MM; B5 salts, phytohormone free, 3\% (w/v) sucrose, $0.8 \%(\mathrm{w} / \mathrm{v})$ agar, $50 \mathrm{mg} / \mathrm{L}$ hygromycin, 500 $\mathrm{mg} / \mathrm{L}$ carbenicillin) for 3 weeks. Roots were inducted on MS medium with $1 \mathrm{mg} / \mathrm{L}$ IBA (Indole-3-butyric acid) and $50 \mathrm{mg} / \mathrm{L}$ hygromycin. Eventually transformed seedlings were planted in pots for further growth. All the 
Table 1. Pathogenicity of leaves from the transgenic plant after 2 days of infection.

\begin{tabular}{|c|c|c|c|c|}
\hline \multirow[t]{2}{*}{ Bacterial strain } & \multirow{2}{*}{ Plant type } & \multirow{2}{*}{$\begin{array}{l}\text { Plant } \\
\text { No. }\end{array}$} & \multicolumn{2}{|c|}{$\begin{array}{c}\text { Pathogenicity } \\
\text { (CFI } / / \mathbf{m l} \text { ) }\end{array}$} \\
\hline & & & $2 \times 10^{4}$ & $2 \times 10^{6}$ \\
\hline \multirow[b]{2}{*}{$\begin{array}{c}\text { Pectobacterium } \\
\text { carotovorum }\end{array}$} & \multirow{2}{*}{ Wild type } & 1 & + & ++ \\
\hline & & 2 & ++ & +++ \\
\hline \multirow[t]{2}{*}{ ssp. carotovorum } & \multirow{2}{*}{$\begin{array}{l}\text { Transgenic } \\
\text { lines }\end{array}$} & $64-12-2$ & \pm & + \\
\hline & & $66-3-1$ & - & + \\
\hline
\end{tabular}

*Diameter of disease lesion; negative (-): $0 \mathrm{~cm} ; \pm: \leq 1 \mathrm{~cm} ;+$ : $1-2 \mathrm{~cm} ;++: 2-3 \mathrm{~cm} ;+++$ : $\geq 4$ $\mathrm{cm}$.

media above contained 3\% (w/v) sucrose ( $\mathrm{pH} 5.8)$ and all explants were cultured under conditions of 16 hrs light (2000 Lux) / 8 hrs dark, at $23-25^{\circ} \mathrm{C}$.

\section{DNA analysis}

Total DNA was extracted from various independent transgenic lines using a DNeasy Plant Kit (Qiagen, Germantown, MD, U.S.A.). Independent BAA- and HPTtransgenic 'T0' and ' $\mathrm{T} 1$ ' lines were screened by polymerase chain reaction (PCR) using genomic DNA of the transgenic plants as template DNA and BAA1 gene-specific primers and hygromycin-resistance gene specific primers. The reaction conditions for the PCR were: 1 cycle of $94^{\circ} \mathrm{C}$ for $1 \mathrm{~min}$ and 30 cycles of $94^{\circ} \mathrm{C}, 30 \mathrm{sec} ; 55^{\circ} \mathrm{C}, 30 \mathrm{sec}$; and $72^{\circ} \mathrm{C}, 1 \mathrm{~min}$ and 1 cycle of $72^{\circ} \mathrm{C}$ for $10 \mathrm{~min}$. PCR amplifications were performed in a Minicycler (MJ Research, Waltham, MA, U.S.A.) using the following primers, HPT specific primers (5'-GCG TGA CCT ATT GCA TCT CC-3' and 5'-TTC TAC ACA GCC ATC GGT CC-3') and BAA1-gene specific primers used in the cloning of the gene.

\section{RNA analysis}

Total RNA was isolated from Chinese cabbage using the TRIzol method (Invitrogen, Carlsbad, CA, U.S.A.). In all cases, RNA was treated with RNase-free DNase and the DNase removed according to the manufacturer's instructions (AMBION, Austin, TX, U.S.A.). RNA was quantified in a spectrophotometer at $260 \mathrm{~nm}$. Total RNA (5 $\mu \mathrm{g})$ was reverse transcribed in $20 \mu \mathrm{l}$ reactions using random hexamers (GE Healthcare Bio-Sciences Corp., Piscataway, NJ, U.S.A.), RNaseH-free reverse transcriptase (Fermentas Life Sciences, Burlington, ON, Canada) and GeneAmplimer pAW 109 RNA (2.5 x 105 copies; Applied Biosystems, Foster City, CA, U.S.A.). The reaction was diluted 50 -fold and $5 \mu$ ladded to a $25 \mu$ PCR amplification reaction containing the $B A A$ gene-specific primers $\mathrm{BAA}-\mathrm{F}$ and BAA-R, as described above. Amplification of the constitutively-expressed gene encoding actin was used as a loading control (actin primers: 5'-ATG GTT GGG ATG GGT CAA AAA-3' and 5'-ACG GAG CTC GTT GTA GAA AGT-3'). Amplification of GeneAmplimer pAW 109 RNA (primers: 5'-CAT GTC AAA TTT CAC TGC CTT CAT C-3' and 5'-TGA CCA CCC AGC CAT CCT T-3') was used as a positive control for the RT-PCR (reverse transcription PCR) reaction efficiency. PCR reactions were separated by agarose gel electrophoresis and stained with ethidium bromide. In order to obtain semi-quantitative results, the number of cycles used for PCR amplification of each gene was adjusted so as to obtain barely-visible bands on agarose gels.

The expression of $B A A 1$ gene was quantitated using actin gene as a reference gene. The cDNA was diluted 100-fold for real-time quantitative PCR experiments (RT-qPCR)using SmartCycler II (Takara, Shiga, Japan) and SYBR RT-PCR kit (Perfect Real Time, Takara, Shiga, Japan). The genes encoding $B A A$ and actin were amplified using gene-specific primers designed using the Primer Express 1.5 software package (Applied Biosystems, Foster City, CA, U.S.A.). The primers for BAA (5'-CTC TAT CGG AGC AAG AAG TTC TCG3' and 5'-GCC ACA CCG TTG TTA GAT ATG ATG3') and actin (primers described above) amplified 103bp and 167-bp fragments, respectively. The SYBR Green I incorporated into amplified DNA was detected and the relative expression was calculated based on the standard curve from the actin gene expression. The reactions were performed three times and the mean value and standard deviation were used for the result. The expression level of the actin was considered as 1 and the relative amount of the expression level of $B A A 1$ gene to that of actin was designated in the Figure.

\section{Preparation of antibody and immunoblotting}

Polyclonal antibody was prepared against N- and C-terminal peptides of BAA (MAEYGRVYKDNDEKMRRFC and CSYVRSNDESMKYA-NH2, respectively) by subcutaneous immunization of a rabbit with $200 \mu \mathrm{g}$ peptide in Freund's complete adjuvant. Subsequently, two booster injections containing $150 \mu \mathrm{g}$ peptide in Freund's incomplete adjuvant were administered at 2-week intervals. The antibody titer was estimated by indirect ELISA. Briefly, total protein and BSA $(200 \mu \mathrm{g} / \mathrm{ml})$ were coated in 96 well and incubated for 2 hrs at RT. After washing three times and incubated with blocking buffer overnight and washed three times. $100 \mu \mathrm{l}$ of diluted (1:500) anti BAA-antiserum was incubated for $2 \mathrm{hrs}$ and washed three times. $100 \mu \mathrm{l}$ of diluted HRP-conjugated goat anti-mouse IgM was incubated and the excess antibody was washed out. The color development was performed by incubating with substrate for $30 \mathrm{~min}$ and was determined by ELISA reader at $415 \mathrm{~nm}$. Total protein was extracted from transgenic lines and used for the Western blot analysis. Protein extracts from untransformed plants were used as negative controls. Protein samples were separated by electrophoresis on 15\% SDS-polyacrylamide gels, followed by electrotransfer onto nitrocellulose membranes (Hybond ECL, GE Healthcare Bio-Sciences Corp., Piscataway, NJ, U.S.A.). The immunoblots were then 
a

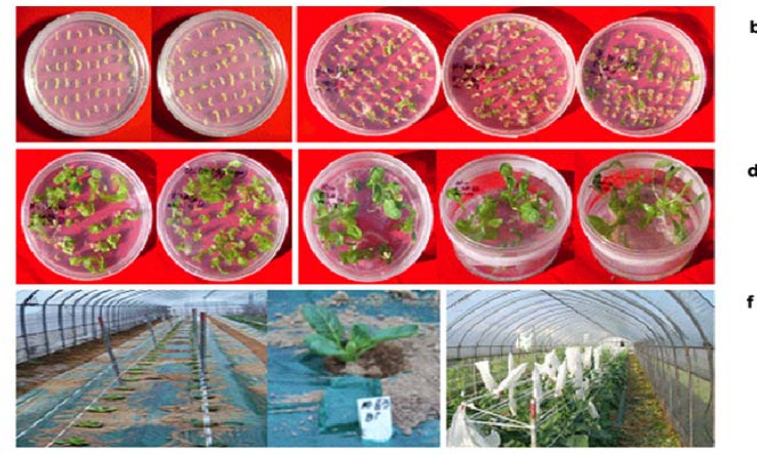

Figure 2. 'Osome' (Brassica rapa L.) plants transformed with pIG121Hm vector containing BAA1 gene. (a) Callus formation. (b) and (c) Multi-shoot differentiation. (d) Regenerated plants in rooting medium. Initial selection of regenerated explants by culturing on a hygromycin and carbenicillin containing MS medium, multiple shoots were obtained after 2 months of culture. For a complementary step of selection, putative transgenic shoots were transferred to $1 / 2 \mathrm{MS}$ basal medium supplemented with $100 \mathrm{mg} / \mathrm{L}$ kanamycin and $500 \mathrm{mg} / \mathrm{L}$ carbenicillin. (e) Acclimation of transgenic plants. (f), Obtaining of selfing seed (T1) after vernalization.

hybridized with antibody against BAA and alkaline phosphatase detection performed, as per the manufacturer's instructions (GE Healthcare Bio-Sciences Corp., Piscataway, NJ, U.S.A.).

\section{Bioassay for transgenic plants}

An in planta bacterial bioassay was performed on 20 seedlings from each transgenic line as well as nontransgenic control plants at 25 days after germination. $P$. carotovorum ssp. carotovorum was obtained from the Korean Agricultural Culture Collection (KACC, http://kacc.rda.go.kr/eng/) at the National Institute of Agricultural Science and Technology, RDA, Suwon, Korea. Bacteria were grown for 1 or $2 \mathrm{~d}$ in $85-\mathrm{mm}$ plates containing NA agar medium (5 g peptone, $3 \mathrm{~g}$ beef extract, 2 g yeast extract and $15 \mathrm{~g}$ Bacto-agar per L) at $28^{\circ} \mathrm{C}$. Sterile water $(2 \mathrm{~mL}$ ) was added to each plate and freshly-cultivated bacteria were scraped gently from the agar medium with a sterile glass rod. After centrifugation at $5,000 \times \mathrm{g}$, the bacterial pellet was resuspended in sterile water and adjusted to $\mathrm{OD}_{600}=0.1$. Leaves were inoculated with the bacterial suspension by syringe infiltration at the concentration of CFU (colony forming unit) of $2 \times 10^{4} / \mathrm{mL}$ and $2 \times 10^{6} / \mathrm{mL}$. Inoculated plants were transferred to a growth chamber and incubated at $28^{\circ} \mathrm{C}$ under continuous light, then checked 12 to 96 hrs after inoculation. Control plants were treated similarly using sterile water. All the bioassays were performed three times and the pathogenicity was determined by the diameter of the disease lesion on the leaves of the plants. The mean values of the diameter were calculated and grouped to 5 groups depending on the size of the diameter. When there was no lesion, we assigned as negative (-); for lesion diameter of $1 \mathrm{~cm}$, as \pm ; for lesion diameter of $1 \sim 2 \mathrm{~cm}$, as + ; for lesion diameter of $2 \sim 3 \mathrm{~cm}$, as ++ ; for lesion diameter larger than $4 \mathrm{~cm}$, as +++ at 2 days after infection.

\section{RESULTS}

\section{Transgenic Chinese cabbage}

The construct of $B A A 1$ gene encoding bromelain protease under CaMV $35 \mathrm{~S}$ promoter (Figure 1) was transformed into A. tumefaciens LBA4404 using electroporation and transgenic plants were generated by Agrobacteriummediated transformation (Hélias et al. 2000).

After Agrobacterium tumefaciens-mediated transformation, transformants were selected for hygromycin resistance. 19 hygromycin resistant calli were obtained after hygromycin selection, from which 8 independent plants were regenerated. Transformants started to produce callus after 10 days-culture in the induction medium, an amorphous mass of cells appeared from the callus during the late period of the second generation of the culture, and many multishoots appeared from the third generation of the culture (Figure 2a). After culture in the regeneration medium and when the length of the plantlets reached 7-8 $\mathrm{cm}$, the shoots were induced to form roots (Figure 2b). The rooted individuals were transferred to the pot to induce flowering by treatment at $8-10^{\circ} \mathrm{C}$ for 40 days. The flowered individuals were bud pollinated to produce T1 (Figure 2c and Figure 2d).

The presence of BAA1 in the 8 independent T1 lines was confirmed by PCR of genomic DNA, which generated an approx $1 \mathrm{~Kb}$ fragment with $B A A 1$ gene specific primers as expected, whereas no DNA could be amplified from untransformed (control) plants (Figure 3). The HPT specific primers produced a 710 bp fragment in the transgenic plants as well as the plasmid vector.

\section{Expression of BAA in transgenic plants}

Semi-quantitative RT-PCR was performed to measure the expression of $B A A 1$ in the transgenic $\mathrm{T} 1$ lines. All $\mathrm{T} 1$ lines examined showed detectable expression of $B A A 1$ gene (data not shown). Real-time PCR was also used to measure $B A A 1$ mRNA expression levels in the leaves of transgenic plants and all the transgenic lines showed high-levels of $B A A 1$ expression, especially in line number 64-12-2 and 66-3-1 as shown in Figure 4.

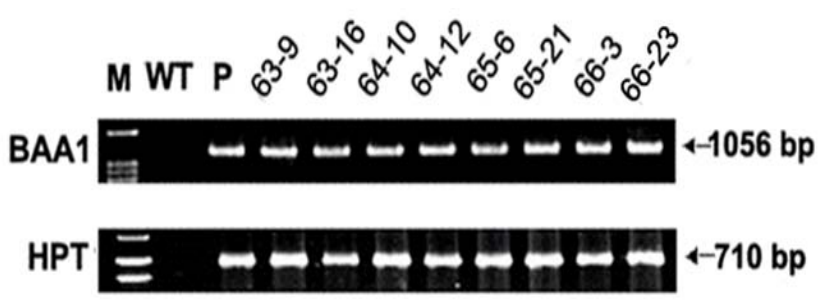

Figure 3. PCR amplification of $B A A 1$ from genomic DNA of transgenic Chinese cabbage (Brassica rapa L.) plants. Amplification products were separated by $1.2 \%$ agarose gel electrophoresis. M: molecular weight marker; WT: wild-type (negative control); P: plasmid pIG $121 \mathrm{Hm}$ containing BAA1 gene (positive control); and HPT: hygromycin phosphotransferase gene. Lanes 4-11, independent transgenic T1 lines. 
Western blot analysis of these transgenic plants identified a band with a molecular mass of about $39 \mathrm{KD}$, corresponding to the predicted size of $B A A 1$, whereas no equivalent band was observed in the untransformed control (Figure 5a). Consistent with the real-time PCR result, transgenic lines, 64-12-2 and 66-3-1, showed the highest expression of $B A A 1$ protein.

Using anti-BAA antibodies, $B A A 1$ protein levels in the leaf tissues of T2 transgenic plant lines B64-12-2 and B66-3-1 were determined by ELISA. The amount of plant BAA1 protein was estimated by comparing the relative light units (RLU) emitted by a known amount of a BAA oligopeptideantibody complex with that emitted by a known amount of transformed plant total soluble protein (TSP). BAA levels were expressed as a percentage of total soluble plant protein (\% TSP; Figure 5b). In the leaf tissues of the B66-3 transgenic line, BAA1 represented $1.6 \%$ of total protein. Western blot analysis was also used to estimate recombinant $B A A 1$ yield, in a side-by-side comparison with LTB (lipid transfer protein) samples of known concentration. Direct comparison of band intensities indicated that transgenic samples contained ca. $320 \mathrm{ng}$ $B A A 1$ protein in $20 \mu \mathrm{g}$ TSP, also corresponding to ca. $1.6 \%$, which is in agreement with the results of the quantitative ELISA. Therefore, based on the ELISA and Western blot assays, $1 \mathrm{~g}$ of leaf tissue (fresh weight) from the transgenic Chinese cabbage plants contained 50-55 $\mu \mathrm{g}$ of recombinant plant-synthesized BAA1 protein.

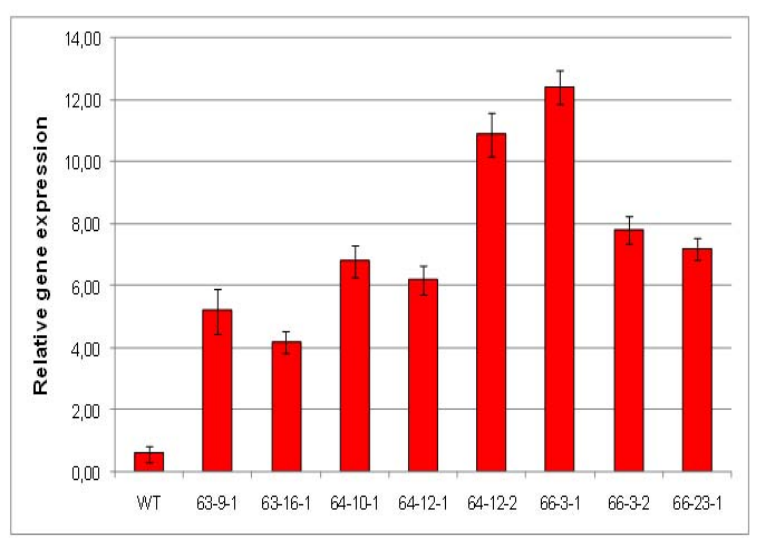

Figure 4. Quantitation of the Real-Time PCR analysis of RNA extracted from transgenic Chinese cabbage T2 lines and wild type control. Relative gene expression of $B A A 1$ was designated as values compared to the expression of actin gene. Error bars show the standard deviation of the mean for three replicate measurements. WT: Wild type plant of cabbage, Lane 2-9, Independent transgenic event lines.

\section{Transgenic BAA Chinese cabbage plants exhibit enhanced soft rot disease resistance}

In order to test the resistance to bacterial pathogen, we selected Chinese cabbages of transgenic lines, 64-12-2 and 66-3-1 that showed high expression of BAA1 protein. We used the soft rot pathogen $P$. carotovorum ssp. carotovorum, isolated from a wild-type Chinese cabbage cultivar, to infect transgenic and wild-type control plants at the 25 days after germination. Following infection with 2 $\mathrm{x} 10^{4} \mathrm{CFU}$, disease symptoms appeared on controls but not transgenic plants 2 days after infection as shown in Figure 6. Following infection with $2 \times 10^{6} \mathrm{CFU}$, control plants exhibited severe soft rot disease symptoms by day 2 and died by day 4, whereas the transgenic lines showed much weaker symptoms compared to control plants (Figure 6, Table 1) by day 2 and the leaves were dead by day 4 . We determined the severity of pathogenicity as diameter of disease lesion of the leaves of the plants two days after infection. The mean values of the diameter were calculated and grouped to 5 groups depending on the size of the disease lesion and the result was shown in Table 1. Figure 6 and Table 1 clearly shows that transgenic plants harboring $B A A 1$ gene exhibited weaker or no symptoms of soft rot compared to control nontransgenic plants.

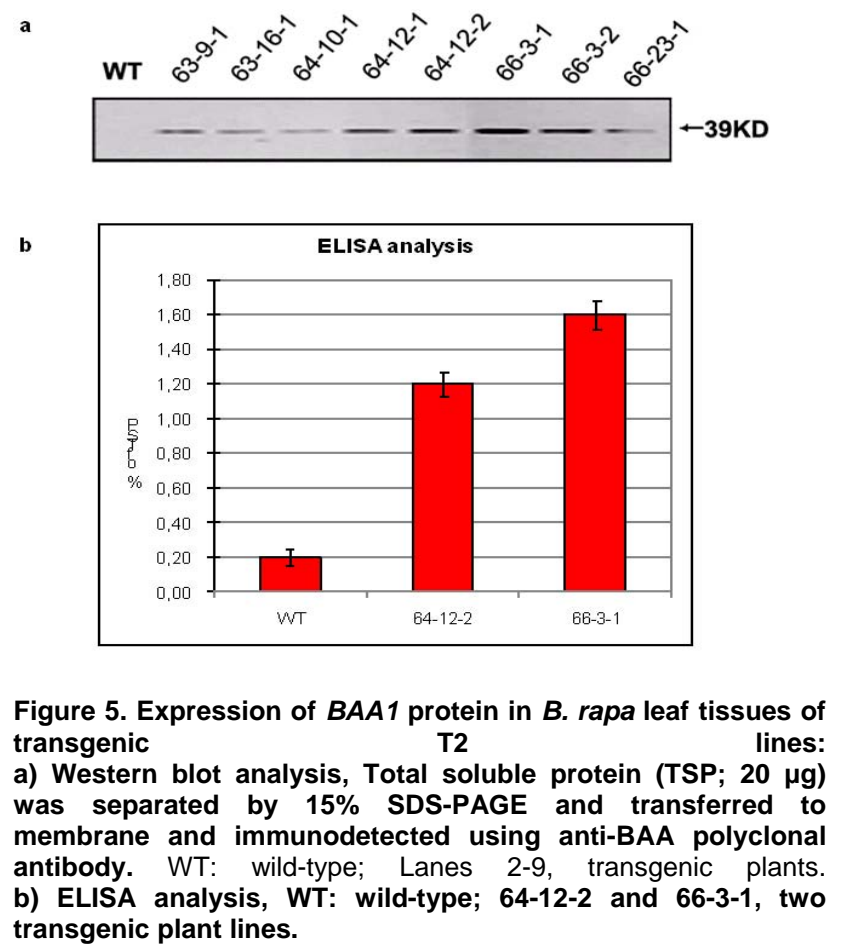

This study demonstrated that constitutive expression of $B A A 1$ bromelain gene from pineapple stems in $B$. rapa confers enhanced resistance to bacterial soft rot disease caused by $P$. carotovorum ssp. carotovorum. At this moment we do not know the mechanism of the increased resistance to soft rot. The increase in the resistance to pathogenic infection might be a result of the process of programmed death as found in the developmental programmed cell death involving proteases (Beers et al. 2000).

A number of molecular engineering strategies have been employed in the pursuit of increased plant resistance towards 
bacterial disease; these have included the introduction of non-plant foreign genes such as those encoding antibacterial properties, or hypersensitive cell death (HCD)associated genes (Shen et al. 2000; Verberne et al. 2000). For example, overexpression of the $R 2 R 3 M Y B$-related gene or AtMYB30 leads to the induction of HCD and pathogen resistance (Vailleau et al. 2002). Similarly, overexpression of the serine/threonine kinase Pti1 in tobacco accelerates HCD and resistance to $P$. syringae pv. tabaci infection (Zhou et al. 1995).

Similar resistance to bacterial pathogens has been observed in transgenic plants expressing expI (Fray et al. 1999; Mae et al. 2001) and hrap (Ger et al. 2002; Pandey et al. 2005). Whatever the mechanism is, our results suggest that $B A A 1$ could be utilized for protecting plants from attack by bacterial pathogens. Further investigation is required to elucidate the cysteine protease interaction and identify other proteins involved in the defense system in B. rapa.

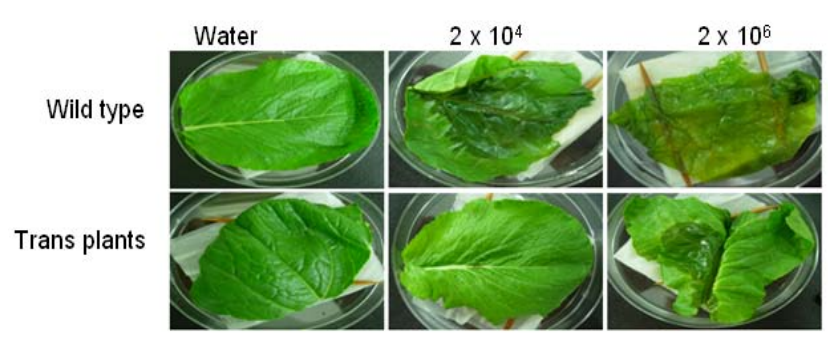

Pectobacterium carotovorum ssp. carotovorum

Figure 6. Bacterial disease resistance is enhanced in transgenic $B$. rapa plants. Samples are shown 2 days after leaf infection with $2 \times 10^{4}$ and $2 \times 10^{6} \mathrm{CFU}$ of P.carotovorum ssp. carotovorum.

\section{REFERENCES}

BEERS, Eric P.; WOFFENDEN, Bonnie J. and ZHAO, Chengsong. Plant proteolytic enzymes: possible roles during programmed cell death. Plant Molecular Biology, October 2000, vol. 44, no. 3, p. 399-415.

BEYENE, Getu; FOYER, Christine H. and KUNERT, Karl J. Two new cysteine proteinases with specific expression patterns in mature and senescent tobacco (Nicotiana tabacum L.) leaves. Journal of Experimental Botany, March 2006, vol. 57, no. 6, p. 1431-1443.

BROEKAERT, W.F.; CAMMUE, B.P.A.; DE BOLLE, M.F.C.; THEVISSEN, K.; DE SAMBLANX, G.W. and OSBORN, R.W. Antimicrobial peptides from plants. Critical Reviews in Plant Sciences, 1997, vol. 16, no. 3, p. 297-323.

DIXON, R.A. The phytoalexin response: elicitation, signaling and control of host gene expression. Biological
Reviews of the Cambridge Philosophical Society, 1986, vol. 61, p. 239-291.

FRAY, Rupert G.; THROUP, John P.; DAYKIN, Mavis; WALLACE, Andrew; WILLIAMS, Paul; STEWART, Gordon S.A.B. and GRIERSON, Donald. Plants genetically modified to produce $N$-acyl-homoserine lactones communicate with bacteria. Nature Biotechnology, October 1999, vol. 17, no. 10, p. 1017-1020.

GER, Mang-Jye; CHEN, Cheng-Hsien; HWANG, Shaw-Yhi; HUANG, Hsiang-En; PODILE, Appa Rao; DAYAKAR, Bradi Venkata and FENG, Teng-Yung. Constitutive expression of hrap gene in transgenic tobacco plant enhances resistance against virulent bacterial pathogens by induction of a hypersensitive response. Molecular Plant-Microbe Interactions, August 2002, vol. 15, no. 8, p. 764-773.

HELIAS, V.; ANDRIVON, D. and JOUAN, B. Development of symptoms caused by Erwinia carotovora ssp. atroseptica under field conditions and their effects on the yield of individual potato plants. Plant Pathology, February 2000, vol. 49, no. 1, p. 23-32.

KIKUMOTO, T. Studies on soft rot disease of Chinese cabbage in Japan. In: TALAKAR, T.S. and GRIGGS, T.D. eds. Chinese Cabbage. Proceedings of the First International Symposium AVRDC. Shanhua, Tainan, Taiwan, 1981, p. 113127.

LAM, Eric. Vacuolar proteases livening up programmed cell death. Trends in Cell Biology, March 2005, vol. 15, no. 3, p. 124-127.

LI, C.W. The origin, evolution, taxonomy and hybridization of Chinese cabbage. In: TALAKAR, T.S. and GRIGGS, T.D. eds. Chinese cabbage. Proceedings of the First International Symposium AVRDC. Shanhua, Tainan, Taiwan, 1981, p. 3-10.

LINKE, Christoph; CONRATH, Uwe; JEBLICK, Wolfgang; BETSCHE, Thomas; MAHN, Andreas; DURING, Klaus and NEUHAUS, H. Ekkehard. Inhibition of the plastidic ATP/ADP transporter protein primes potato tubers for augmented elicitation of defense responses and enhances their resistance against Erwinia carotovora. Plant Physiology, August 2002, vol. 129, no. 4, p. 1607-1615.

LINTHORST, H.J.M. Pathogenesis-related proteins of plants. Critical Reviews in Plant Sciences, 1991, vol. 10, p. 123-150.

LUERTI, M. and VIGNALI, M.L. Influence of bromelain on penetration of antibiotics in uterus, salpinx and ovary. Drugs under Experimental and Clinical Research, 1978, vol. 4, no. 1, p. $45-48$.

MAE, Andres; MONTESANO, Marcos; KOIV, Viia and PALVA, E. Tapio. Transgenic plants producing the bacterial pheromone $N$-Acyl-Homoserine lactone exhibit enhanced 
resistance to the bacterial phytopathogen Erwinia carotovora. Molecular Plant-Microbe Interactions, September 2001, vol. 14, no. 9, p. 1035-1042.

MAURER, H.R. Bromelain: biochemistry, pharmacology and medical use. Cellular and Molecular Life Sciences, August 2001, vol. 58, no. 9, p. 1234-1245.

MURASHIGE, Toshio and SKOOG, Folke. A revised medium for rapid growth and bioassays with tobacco tissue cultures. Physiologia Plantarum, July 1962, vol. 15, no. 3, p. 473-497.

MUTA, E.; ARAMAKI, H.; TAKATAY; KONO, A.; OKAMOTO, Y. and OTA, S. Cloning and sequencing of fruit bromelain [online]. January 1993, D14059. Available from Internet:

http://www.ncbi.nlm.nih.gov/entrez/viewer.fcgi?db=nuccor e\&id=2342495.

MYNOTT, Tracey L.; CROSSETT, Ben and PRATHALINGAM, S. Radhika. Proteolytic inhibition of Salmonella enterica serovar typhimurium-induced activation of the mitogen-activated protein kinases ERK and JNK in cultured human intestinal cells. Infection and Immunity, January 2002, vol. 70, no. 1, p. 86-95.

ORSINI, Roger A. Bromelain. Plastic and Reconstructive Surgery, December 2006, vol. 118, no. 7, p. 1640-1644.

PANDEY, Ajay-Kumar; GER, Mang-Jye; HUANG, Hsiang-En; YIP, Mei-Kuen; ZENG, Jiqing and FENG, Teng-Yung. Expression of the hypersensitive responseassisting protein in Arabidopsis results in hairpin-dependent hypersensitive cell death in response to Erwinia carotovora. Plant Molecular Biology, November 2005, vol. 59, no. 5, p. 771-780.

SHAFER, W.M.; KATZIF, S.; BOWERS, S.; FALLON, M.; HUBALEK, M.; REED, M.S.; VEPREK, P. and POHL, J. Tailoring an antibacterial peptide of human lysosomal cathepsin $\mathrm{G}$ to enhance its broad-spectrum action against antibiotic-resistant bacterial pathogens. Current Pharmaceutical Design, April 2002, vol. 8, no. 9, p. 695702.

SHEN, Songhai; LI, Qingshun; HE, Sheng-Yang; BARKER, Kenneth R.; LI, Debao and HUNT, Arthur G. Conversion of compatible plant-pathogen interactions into incompatible interactions by expression of the Pseudomonas syringae pv. syringae $61 \mathrm{hrmA}$ gene in transgenic tobacco plants. Plant Journal, July 2000, vol. 23, no. 2, p. 205-213.

SUBBAIAH, Chalivendra C.; KOLLIPARA, Krishna P. and SACHS, Martín M. A $\mathrm{Ca}^{2+}$-dependent cysteine protease is associated with anoxia-induced root tip death in maize. Journal of Experimental Botany, April 2000, vol. 51, no. 345, p. 721-730.
TANI, Kenji; OGUSHI, Fumitaka; SHIMIZU, Teruki and SONE, Saburo. Protease-induced leukocyte chemotaxis and activation: roles in host defense and inflammation. The Journal of Medical Investigation, August 2001, vol. 48, no. 3-4, p. 133-141.

TAUSSIG, Steven J. and BATKIN, Stanley. Bromelain, the enzyme complex of Pineapple (Ananas comusus) and its clinical application. An update. Journal of Ethnopharmacology, February-March 1988, vol. 22, no. 2, p. 191-203.

TINOZZI, S. and VENEGONI, A. Effect of bromelain on serum and tissue levels of amoxycillin. Drugs under Experimental and Clinical Research, 1978, vol. 4, p. 39-44.

TOTH, I.K.; NEWTON, J.A.; HYMAN, L.J.; LEES, A.K.; DAYKIN, M.; ORTORI, C.; WILLIAMS, P. and FRAY, R.G. Potato plants genetically modified to produce $N$-acylhomoserine lactones increase susceptibility to soft rot Erwiniae. Molecular Plant-Microbe Interactions, August 2004, vol. 17, no. 8, p. 880887.

VAILLEAU, Fabienne; DANIEL, Xavier; TRONCHET, Maurice; MONTILLET, Jean-Luc; TRIANTAPHYLIDES, Christian and ROBY, Dominique. A R2R3-MYB gene, AtMYB30, acts as a positive regulator of the hypersensitive cell death program in plants in response to pathogen attack. Proceedings of the National Academy of Sciences of the United States of America, July 2002, vol. 99, no. 15, p. 10179-10184.

VAN LOON, L.C. and VAN KAMMEN, A. Polyacrylamide disc electrophoresis of the soluble leaf proteins from Nicotiana tabacum var. 'Samsun' and 'Samsun NN'. II. Changes in protein constitution after infection with TMV. Virology, February 1970, vol. 40, no. 2, p. 199-211.

VERBERNE, Marianne C., VERPOORTE, Rob; BOL, John F.; MERCADO-BLANCO, Jesus and LINTHORST, Huub J.M. Overproduction of salicylic acid in plants by bacterial transgenes enhances pathogen resistance. Nature Biotechnology, July 2000, vol. 18, no. 7, p. 779-783.

YAMAGISHI, Hiroshi; YOSHIKAWA, Hiroaki and YUI, Susumu. Leaf morphology and soft rot resistance in offspring of a somatic hybrid between Chinese cabbage and kale (Cruciferae). Euphytica, June 1990, vol. 47, no. 3, p. 215-221.

YIP, Mei-Kuen; HUANG, Hsiang-En; GER, Mang-Jye; CHIU, Shih-Hua; TSAI, Yuh-Chih; LIN, Chin-I and FENG, Teng-Yung. Production of soft rot resistant calla lily by expressing a ferredoxin-like protein gene ( $p f l p)$ in transgenic plants. Plant Cell Reports, April 2007, vol. 26, no. 4, p. 449-457.

YOSHIKAWA, H.; SAWADA, T.; YAMAGISHI, H. and YUI, S. Soft rot resistance of progenies of somatic hybrid: Chinese cabbage plus Kale. Journal of Japan Society of 
Horticultural Science, 1989, vol. 58, p. 190-191.

YUN, D.-J.; BRESSAN, R.A. and HASEGAWA, P.M. Plant antifungal proteins. In: JANICK, J. ed. Plant Breeding Reviews. John Wiley, New York, 1997, vol. 14, p. 39-88.

ZHOU, Jianmin; LOH, Ying-Tsu; BRESSAN, Ray A. and MARTIN, Gregory B. The tomato gene Pti1 encodes a serine/threonine kinase that is phosphorylated by Pto and is involved in the hypersensitive response. Cell, December 1995, vol. 83, no. 6, p. 925-935. 